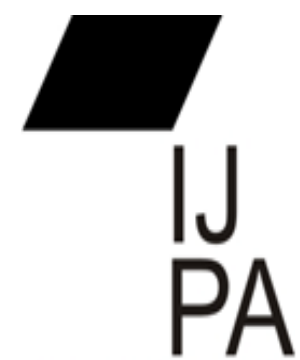

ISSN $2460=0369$

\section{AKUNTABILITAS PEMERINTAHAN DESA DALAM PENGELOLAAN ANGGARAN PEMBANGUNAN DESA}

\author{
Ummi Zakiyah, Ginesta Monra Jelis Sihombing, Nadaa Syafira, \\ Siti Hofifah, Mohamad Yusran Al Aufar \\ Prodi Ilmu Pemerintahan \\ Universitas 17 Agustus 1945 Jakarta \\ ummi.zakiyah@gmail.com
}

Abstract, The purpose of this study is to determine the application of the principles of transparency and accountability in the management of APBDes which includes planning, implementation, reporting, and accountability activities. The research method used is a qualitative method with a descriptive approach. The respondents of this study consisted of the village secretary, treasurer of the PKK, and community representatives. Data collection techniques are by interview, observation and documentation. Data analysis techniques began with data collection, data reduction, data presentation and conclusion drawing. The results of this study indicate that the apparatus of the Pusaka Rakyat Village, Tarumajaya District has applied the principles of transparency and accountability in the management of the APBDes. APBDes planning and implementation has applied the principles of transparency and accountability. While APBDes accountability physically shows an accountable implementation. The main obstacle is the disbursement of funding sources that are not according to plan.

Keywords: Accountability, APBDes

Abstrak, Tujuan dari penelitian ini adalah untuk menentukan penerapan prinsip-prinsip transparansi dan akuntabilitas dalam pengelolaan APBDes yang mencakup kegiatan perencanaan, pelaksanaan, pelaporan, dan akuntabilitas. Metode penelitian yang digunakan adalah metode kualitatif dengan pendekatan deskriptif. Responden penelitian ini terdiri dari sekretaris desa, bendahara PKK, dan perwakilan masyarakat. Teknik pengumpulan data adalah dengan wawancara, observasi dan dokumentasi. Teknik analisis data dimulai dengan pengumpulan data, reduksi data, penyajian data dan penarikan kesimpulan. Hasil penelitian ini menunjukkan bahwa aparatur Desa Pusaka Rakyat, Kecamatan Tarumajaya telah menerapkan prinsip transparansi dan akuntabilitas dalam pengelolaan APBDes. Perencanaan dan implementasi APBDes telah menerapkan prinsip transparansi dan akuntabilitas. Sementara akuntabilitas APBDes secara fisik menunjukkan implementasi yang akuntabel. Kendala utama adalah pencairan sumber pendanaan yang tidak sesuai dengan rencana.

Kata Kunci : Akuntabilitas , APBDes 


\section{PENDAHULUAN}

Akuntabilitas adalah kewajiban untuk memberikan pertanggung- jawaban atau menjawab dan menerangkan kinerja serta tindakan seseorang / pimpinan suatu unitorganisasi kepada pihak yang memiliki hak atau yang berwenang memintapertanggungjawaban. Akuntabilitas akan semakin baik jika didukung oleh suatu sistemakuntansi yang menghasilkan informasi yang akurat, handal, tepat waktu, serta dapat dipertanggungjawabkan (Ayu Komang, 2014). Sejalan dengan hal tersebut,akuntabilitas publik adalah kewajiban agen (pemerintah) untuk mengelola sumber daya,melaporkan, dan mengungkapkan segala aktivitas dan kegiatan yang berkaitan denganpenggunaan sumber daya publik kepada pemberi mandat (prinsipal). (Mahmudi,2010:23).Akuntabilitas dalam pemerintah desa sebagaimana diungkapkan oleh Sukasmanto(dalam Sumpeno; 2011:222) melibatkan kemampuan pemerintah desa untuk mempertanggungjawabkan kegiatan yang dilaksanakan dalam kaitannya dengan masalah pembangunan dan pemerintahan desa. Pertanggungjawaban yang dimaksud adalah masalah finansial yang terdapat dalam Anggaran Pendapatan Belanja Desa (APBDes)dengan Pendapatan Asli Desa (PADes), Alokasi Dana Desa (ADD), dan Dana Desa (DD) termasuk komponen di dalamnya.

Desa adalah kesatuan masyarakat hukum yang memiliki batas wilayah yang berwenang untuk mengatur dan mengurus urusan pemerintahan, kepentingan masyarakat setempat berdasarkan prakarsa masyarakat, hak asal usul, dan/atau hak tradisional yang diakui dan dihormati dalam sistem pemerintahan Negara Kesatuan Republik Indonesia sesuai dengan UU No. 6 Tahun 2014. Dari segi politis undang undang ini memberikan sebuah pelimpahan wewenang dari pemerintah pusat kepada pemerintah daerah. Pemerintah daerah mempunyai kewenangan yang disebut otonomi desa. Sulumin (2015) mendefinisikan otonomi desa merupakan kewenangan bagi desa dalam mengatur kepentingan masyarakat sesuai dengan prakarsa yang ada. Salah satu bentuk kepedulian pemerintahterhadap pengembangan wilayah pedesaaan adalah adanya anggaran pembangunan secara khusus yang dicantumkan dalam APBD (Anggaran Pendapatan dan Belanja Daerah) untuk pembangunan wilayah pedesaan, yakni dalam bentuk ADD (Alokasi Dana Desa). Itikad baik pemerintah pusat akan adanya ADD ditunjukkan dengan terbitnya Surat Edaran MendagriNo 140/640/SJ yang menjelaskan tentang AlokasiDana Desa. ADD adalah wujud dari proses dankeadilan anggaran yang 
selama ini diidamkan olehdesa. Dengan adanya ADD diharapkan desa dapat melatih diri dan belajar tentang bagaimana melakukan perencanaan dan pengelolaaan keuangan dalam menyelenggarakan roda pemerintahan dan pemberdayaan masyarakat sesuai dengan kebutuhan dan prioritas serta potensi masing-masing desa. Upaya pembangunan pedesaan meliputi empat upaya besar diantaranya pemberdayaan ekonomi masyarakat desa dalam rangka peningkatan kapasitas masyarakat (capacity building), meningkatkan kualitas sumber daya manusia pedesaan agar memiliki dasar yang memadai untuk meningkatkan dan memperkuat produktivitas dan daya saing, membangun prasarana (terutama transportasi) agar sumber daya yang ada di pedesaan dapat dimanfaatkan secara optimal, dan membangun kelembagaan pedesaan agar pembangunan pedesaan dapat dilaksanakan secara efektif dan efisien (Kartasasmita, 1996:393).

Namun, dengan ADD ini, tidak sedikit pejabat desa yang menyalahgunakan uang tersebut diantaranya karna korupsi dan juga karna ketidaktahuan apa yang harus dilakukan dalam mengunakan ADD ini yang diberikan oleh pemerintah untuk pembangunan desa. Dalam studi kasus yang saya ambil yaitu saya menyoroti bahwa di desa itu sering terjadi masalah dalam pengelolaan lingkungan dalam pembangunan sehingga saya ingin menyoroti bagaimana langkah langkah yang dilakukan oleh pejabat desa dalam menangani masalah tersebut dari sisi pengelolaan anggaran dana desa. Dengan demikian dalam penelitian ini difokuskan kepada Bagaimana Akuntabilitas Kepala Desa Pusaka Raktyat didalam mengelola Anggaran Pembangunan Desa?

\section{KAJIAN TEORI}

\section{Definisi Desa}

Desa menurut Undang-Undang No. 6 Tahun 2014 adalah "Desa dan desa adat atau yang disebut dengan nama lain, selanjutnya disebut Desa, adalah kesatuan masyarakat hukum yang memiliki batas wilayah yang berwenang untuk mengatur dan mengurus urusan pemerintahan, kepentingan masyarakat setempat, berdasarkan prakarsa masyarakat, hak asal usul, dan/tidak hak tradisional yang diakui dan dihormati dalam sistem pemerintahan Negara Kesatuan Republik Indonesia”.

Dengan diberlakukannya Undang-undang Nomor 6 Tahun 2014 tentang Desa, maka yang menjadi perhatian kita bersama adalah bagaimana selanjutnya pemerintahan desa mengelola keuangan dan mempertanggungjawabkannya. 


\section{Pengertian Anggaran Pendapatan dan Belanja Desa (APBDes)}

Anggaran pendapatan dan belanja desa adalah pertanggung jawaban dari pemegang manajemen desa untuk memberikan informasi tentang segala aktivitas dan kegiatan desa kepada masyarakat dan pemerintah atas pengelolaan dana desa dan pelaksanaan berupa rencana-rencana program yang dibiayai dengan uang desa. Dalam APBDes berisi pendapatan, belanja dan pembiayaan desa.

\section{Fungsi Anggaran Desa}

1. Alat Perencanaan

Anggaran merupakan alat pengendali manajemen desa dalam rangka mencapai tujuan. Anggaran desa digunakan untuk merencanakan kegiatan apa saja yang akan dilakukan oleh desa beserta rincian biaya yang dibutuhkan dan rencana sumber pendapatan yang akan diperoleh desa.

2. Alat Pengendalian

Anggaran berisi rencana detail atas pendapatan dan pengeluaran desa dimaksudkan dengan adanya anggaran, semua bentuk pengeluaran dan pemasukan dapat dipertanggungjawabkan kepada publik. Tanpa adanya anggaran, desa akan sulit mengendalikan pengeluaran dan pemasukan.

3. Alat Kebijakan Fiskal

Dengan menggunakan anggaran dapat diketahui bagaimana kebijaksanaan fiskal yang akan dijalankan desa, dengan demikian akan mudah untuk memprediksi dan mengestimasi ekonomi dan organisasi.

4. Alat Koordinasi dan Komunikasi

Dalam menyusun anggaran, pasti antar unit kerja akan melakukan komunikasi dan koordinasi. Dalam perencanaan dan pelaksanaan anggaran harus dikomunikasikan ke seluruh perangkat desa.

5. Alat Penilaian Kinerja

Perencanaan anggaran dan pelaksanaannya akan menjadi penilaian kinerja perangkat desa. Kinerja perangkat desa akan dinilai berdasarkan pencapaian target anggaran serta pelaksanaan efisien anggaran.

6. Alat Motivasi

Anggaran dapat digunakan untuk memberi motivasi kepada perangkat desa dalam bekerja secara efektif dan efisien. 


\section{Manfaat Anggaran Desa}

1) Sebagai panduan bagi pemerintah desa dalam menentukan strategi kegiatan operasional, dengan melihat kebutuhan dan ketersediaan sumber daya.

2) Sebagai salah satu indikator untuk menentukan besarnya biaya pelayanan yang akan dibebankan masyarakat.

3) Bahan pertimbangan untuk menggali sumber pendapatan lain seperti mengajukan pinjaman.

4) Memberikan kewenangan pada pemerintahan desa dalam penyelenggaraan administrasi desa.

5) Memberi arahan bagi pemerintahan desa dalam penyelenggaraan dan pengawasan pemerintahan desa.

6) Menggambarkan kebijakan pembangunan desa dalam 1 periode anggaran.

\section{Prinsip-Prinsip Penganggaran Desa}

1. Transparansi.

2. Akuntabilitas.

3. Menyangkut kemampuan pemerintah desa untuk membuka peluang bagi seluruh komponen masyarakat untuk terlibat dan berperan serta dalam proses pembangunan desa.

4. Penyelenggaraan pemerintah yang efektif.

5. Pemerintah tanggap terhadap aspirasi yang berkembang di masyarakat.

6. Profesional.

\section{METODE PENELITIAN}

Penelitian ini menggunakan metode penelitian deskriptif dengan pendekatan kualitatif. Sumber data yang digunakan adalah sumber data primer dan sekunder. Metode pengumpulan data dalam penelitian ini yaitu menggunakan wawancara, observasi, dokumentasi.

Untuk mempermudah dan menghindari kesalahpahaman dalam menafsirkan fokus penelitian, maka perlu dilakukan pembatasan pengertian dan penjelasan mengenai fokus penelitian yang akan dilakukan yaitu :

1) Bagaimana pejabat desa melakukan pengelolaan anggaran desa terkait permasalahan yang ada berdasarkan prinsip akuntabilitas. 
2) Bagaimana pejabat desa mempertanggungjawabkan kegiatan yang dilaksanakan dalam kaitannya dengan masalah pembangunan desa.

\section{PEMBAHASAN}

Desa Pusaka Rakyat adalah salah satu desa yang terletak di Kecamatan Tarumajaya yang berada di Kabupaten Bekasi. Desa ini memiliki luas wilayah 634 Ha, dengan batas wilayah sebelah utara Desa Segera Makmur dan Kelurahan Cilingcing DKI Jakarta, sebelah selatan Desa Gapura Muka, sebelah Barat Kampung Rawa Gatel, dan sebelah timur Desa Pahlawan Setia Babelan Bekasi.

\section{Perencanaan}

Pemerintahan Desa Pusaka Rakyat setiap tahun wajib menyusun APBDes. APBDes merupakan pembiayaan terhadap program pembangunan tahunan yang diselenggarakan oleh pemerintah desa. APBDesa yang ditetapkan oleh kepala desa dan BPD, merupakan APBDesa yang ditetapkan dari hasil penyusunan rancangan APBDesa yang dibuat oleh kepala desa dengan mendengarkan aspirasi masyarakat desa. Program pembangunan tahunan desa diturunkan dari program pembangunan jangka menengah desa (lima tahun), yang disebut Rencana Pembangunan Jangkah Menengah Desa (RPJMDesa). RPJMDesa merupakan penjabaran visi misi dari kepala desa, dan setiap tahun harus melaporkan laporan pertanggungjawabkan anggaran pendapatan dan belanja desa (APBDesa).

Mekanisme perencanaan APBDes di Desa Pusaka Rakyat secara kronologis dapat diuraikan sebagai berikut :

1) Kepala Desa selaku penanggungjawab mengadakan musyawarah rencana penggunaan dana.

2) Musyawarah dihadiri oleh Perwakilan Tim dari Kecamatan Tarumajaya, BPD, LPMD, Linmas, Tokoh Masyarakat serta pihak-pihak terkait lainnya.

Tim Pelaksana Desa menyampaikan rancangan penggunaan dana didasarkan pada skala prioritas hasil Musrembangdes yang sudah disepakati di awal.

\section{Pelaksanaan}

Dalam pelaksanaan APBDes, setiap pengeluaran belanja atas beban APBDes harus didukung dengan bukti yang lengkap dan sah. Bukti harus mendapatkan pengesahan oleh sekretaris desa atas kebenaran material yang timbul dari penggunaan bukti dimaksud. Dalam pengelolaan keuangan desa, bendahara desa menggunakan buku administra- 
si keuangan desa, yaitu: buku kas umum. Buku kas umum digunakan oleh bendahara desa untuk mencatat semua penerimaan dan pengeluaran rutin.

\section{Pelaporan}

Pelaporan dilakukan untuk mengetahui perkembangan proses pengelolaan dan penggunaan APBDes yang meliputi :

1) Perkembangan kegiatan dan penyerapan dana.

2) Masalah yang dihadapi dan pemecahannya.

3) Pencapaian hasil penggunaan APBDes.

Laporan pelaksanaan APBDes terdiri dari laporan pendahuluan, laporan masing-masing tahap kegiatan, laporan bulanan dan laporan akhir kegiatan yang disusun secara komprehensif. Pelaporan APBDes telah dibuktikan dengan pertanggungjawaban pelaksanaan program APBDes kepada pemerintah tingkat atasnya dilakukan secara periodik. Sebagai program yang kegiatannya bersiklus tahunan, maka dari perencanaan, implementasi sampai dengan monitoring dan evaluasi juga dilakukan setiap tahun.

Bendahara desa wajib mempertanggungjawabkan penerimaan uang yang menjadi tanggung jawabnya melalui laporan pertanggungjawaban penerimaan kepada kepala desa paling lambat tanggal 10 bulan berikutnya

Terdapat juga laporan pertanggungjawaban pelaksanaan Anggaran Pendapatan dan Belanja Desa (APBDes) antara lain:

a. Peraturan desa tentang pertanggungjawaban pelaksanaan APBDes dan keputusan kepala desa tentang keterangan pertanggungjawaban kepala desa disampaikan kepada Bupati melalui Camat.

b. Waktu penyampaian paling lambat 7 (tujuh) hari kerja setelah ditetapkan

c. Peraturan desa tentang pertanggungjawaban pelaksanaan APBDes dan keputusan kepala desa tentang keterangan pertanggungjawaban kepala desa yang disampaikan kepada bupati untuk dievaluasi sebagai bahan pelaksanaan pembinaan.

\section{Pertanggungjawaban}

Peraturan desa tentang pertanggung jawaban pelaksanaan APBDes dan keputusan kepala Desa Pusaka Rakyat tentang keterangan pertanggungjawaban kepala desa disampaikan kepada Bupati/ Wali kota melalui Camat. Waktu penyampaian paling lambat 7 (tujuh) hari kerja setelah peraturan desa ditetapkan. Sedangkan untuk laporan per- 
tanggungjawaban mengenai pengeluaran pembangunan ditangani langsung oleh pimpinan proyek dan bendahara kecamatan serta dinas-dinas terkait ke kabupaten, karena pembayaran kegiatan pembangunan ini, ditangani langsung oleh bendahara kecamatan dan dinas-dinas terkait.

Anggaran merupakan pernyataan mengenai estimasi kinerja yang hendak dicapai selama periode waktu tertentu yang dinyatakan dalam ukuran finansial, sedangkan penganggaran adalah proses atau metode untuk mempersiapkan suatu anggaran. Perencanaan dan penganggaran merupakan proses yang tak dipisahkan. Output dari perencanaan adalah penganggaran. Jadi perumusan program di dalam perencanaan pada akhirnya bermura pada besarnya kebutuhan anggaran yang harus disediakan. Pengelolaan keuangan desa adalah keseluruhan kegiatan yang meliputi perencanaan, pelaksanaan, pelaporan, dan pertanggungjawaban keuangan desa.

\section{KESIMPULAN}

Anggaran merupakan pernyataan mengenai estimasi kinerja yang hendak dicapai selama periode waktu tertentu yang dinyatakan dalam ukuran finansial, sedangkan penganggaran adalah proses atau metode untuk mempersiapkan suatu anggaran. Perencanaan dan penganggaran merupakan proses yang tak dipisahkan. Output dari perencanaan adalah penganggaran. Jadi perumusan program di dalam perencanaan pada akhirnya bermura pada besarnya kebutuhan anggaran yang harus disediakan. Pengelolaan keuangan desa adalah keseluruhan kegiatan yang meliputi perencanaan, pelaksanaan, pelaporan, dan pertanggungjawaban keuangan desa. penyelenggaraan kewenangan desa bedasarkan hak asal usul dan kewenangan lokal berskala Desa oleh APBDes. Penyelenggaraan kewenangan desa yang ditugaskan oleh Pemerintahan di danai oleh Anggaran Pendapatan dan Belanja Negara atau disebut dengan APBN. Dana Anggaran Pendapatan dan Belanja Negara dialokasikan pada bagian Anggaran Kementrian atau Lembaga dan disalurkan melalui satuan kerja perangkat daerah Kabupaten/Kota. Seluruh pendapatan Desa diterima dan disalurkan melalui rekening kas Desa dan penggunaannya ditetapkan dalam APBDes. Pencairan dana dalam rekening kas desa ditanda tangani oleh Kepala Desa dan Bendahara Desa.

Peraturan desa mengenai anggaran APBDes merupakan salah satu produk hukum lokal yang secara rutin wajib dilaporkan dan direalisasikan oleh pemerintahan desa dalam waktu satu tahun sekali. APBDes merupakan pembiayaan utama untuk 
membangun desa menjadi lebih maju dan baik lagi. Pembiayaan dalam meningkatkan desa dan mengubah desa menjadi lebih maju melalui anggaran pendapatan dan belanja desa (APBDes) yang bersumber dari PADesa, bagi hasil pajak Kabupaten/kota, ADD, Bantuan keuangan pemerintah, pihak ketiga, dan Hibah. Program pembangunan tahunan desa diturunkan dari program pembangunan jangka menengah desa (lima tahun), yang disebut Rencana Pembangunan Jangkah Menengah Desa (RPJMDes).

RPJMDes merupakan penjabaran visi dan misi dari kepala desa terpilih. Setelah RPJMDes ditetapkan dengan peraturan desa, kepala desa bersama badan permusyawaratan desa (BPD) menyusun rencana kerja pemerintahan desa (RKPDes) yang merupakan penjabaran dari RPJMDes bedasarkan hasil musyawarah rencana pembangunan desa. RKPDes adalah rencana kerja tahunan pemerintahan desa dalam menyelenggarakan program pembangunan dan pelayanan di desa. penyusunan RKPDes diselesaikan paling lambat akhir januari tahun anggaran sebelumnya. Anggaran pendapatan dan belanja desa (APBDes) dalam pembuatan peraturan desa perumusannya yang diajukan oleh pemerintahan desa maupun BPD, dalam musyawarah yang diikuti oleh tokoh masyarakat, tokoh agama, tokoh pemuda, RT, RW.

\section{SARAN}

Bedasarkan hasil penelitian yang telah dijelaskan sebelumnya serta penyajian data dan pembahasan bahwasanya diperlukan suatu sosialisasi yang lebih efisiensi agar partisipasi masyarakat dalam pembangunan dan pemberdayaan untuk mewujudkan desa lebih maju lebih menonjol. Dan didalam mengatasi permasalahan yang ada di Desa Pusaka Rakyat agar dapat terselesaikan dengan menghadirkan inovasi-inovasi para pemimpin ataupun perangkat desa didadalam menyelesaikan permasalahan serta diperlukannya kesadaran terhadap masyarakat untuk lebih meningkatkan rasa kepeduliannya terhadap lingkungan sekitar dan juga untuk terus mendorong dan bekerja sama didalam mengatasi permasalahan yang ada. Dan untuk mewujudkan desa lebih transparansi dan akuntabilitas diperlukan suatu partisipasi masyarakat dalam peningkatan program APBDes yang telah ditetapkan oleh kepala desa sesuai dengan aspirasi masyarakat Desa Pusaka Rakyat. 


\section{DAFTAR PUSTAKA}

Amiruddin, (2012). Transparansi Pengelolaan Anggaran Pendapatan dan Belanja Desa di Desa Pertasi Kencana Kecamatan Kalaena Kabupaten Luwu Timur. Otoritas Jurnal Ilmu Pengetahuan, Vol. II No. 1 April 2012.

Anisa, L. N. (2017). Akuntabilitas Pengelolaan Keuangan Desa di Kabupaten Jombang. Jurnal Ilmu Akuntansi, Volume 10 (2).

Faradhiba, L., \& Diana, N. (2018). Akuntabilitas Pemerintahan Desa Dalam Pengelolaan Anggaran Pendapatan Dan Belanja Desa (Apbdes) Studi Kasus di Desa Banjarsari Kecamatan Bandarkedungmulyo-Jombang). Jurnal Ilmiah Riset Akuntansi, 7(07).

Fitriati. (2017). Transparansi dan Akuntabilitas Pengelolaan Anggaran Pendapatan dan Belanja Desa (APBDes) di Desa Tempel Kecamatan KrianSidoarjo.Skripsi. Fakultas Ushuluddin dan Filsafat, Universitas Islam Negeri Sunan Ampel

Karlinayani, S., \& Ningsih, E. S. (2018). Akuntabilitas Pemerintah Desa Dalam Pengelolaan Anggaran Pendapatan Dan Belanja Desa (Studi Pada Alokasi Dana Desa Di Kabupaten Gayo Lues). Jurnal Ilmiah Mahasiswa Ekonomi Akuntansi, 3(2), 309-316.

Nafidah, L. N., \& Anisa, N. (2017). Akuntabilitas pengelolaan keuangan desa di kabupaten Jombang. Akuntabilitas, 10(2), 273-288. 